\title{
PENYUSUNAN LAPORAN KEUANGAN
}
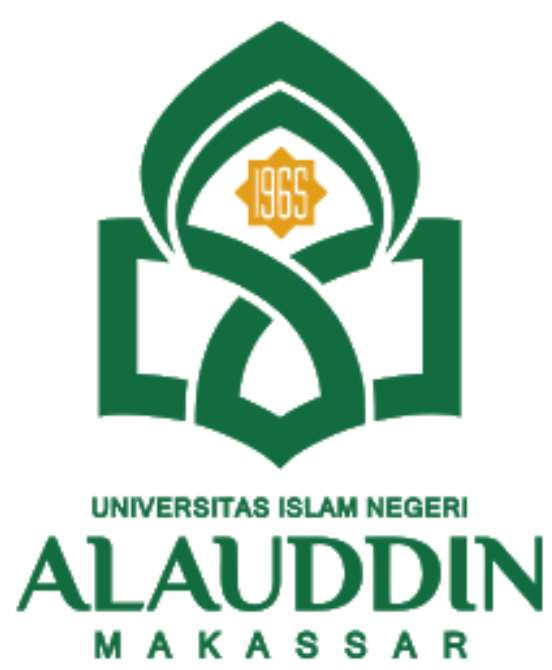

Makalah ini Disusun untuk Memenuhi Tugas pada Mata Kuliah Kewirausahaan

Oleh :

RAHMADANA

90500120025

Rahmadana764@gmail.com

Dosen Pengampu:

Dra. Hj. Nuraeni Gani, MM.

PERBANKAN SYARIAH

FAKULTAS EKONOMI \& BISNIS ISLAM

UNIVERSITAS ISLAM NEGERI ALAUDDIN MAKASSAR 


\section{KATA PENGANTAR}

Puji syukur saya panjatkan kehadirat Tuhan Yang Maha Esa karena rahmat dan hidayah-Nya sehingga Penulis bisa menyelesaikan makalah yang berjudul "Laporan Keuangan".

Tidak lupa penulis mengucapkan terima kasih kepada bapak/ibu dosen yang telah membantu penulis dalam mengerjakan makalah ini. Penulis juga mengucapkan terima kasih kepada teman-teman yang telah memberi kontribusi baik secara langsung maupun tidak langsung dalam pembuatan makalah ini.

Penulis mengakui bahwa ada banyak kekurangan pada makalah ini. Oleh karena itu, kritik dan saran dari seluruh pihak senantiasa penulis harapkan demi kesempurnaan dari makalah ini. Semoga makalah ini dapat membawa pemahaman dan pengetahuan bagi kita semua tentang "Laporan Keuangan”.

Gowa, 27 Desember 2021

Penulis 


\section{DAFTAR ISI}

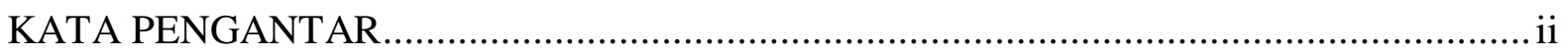

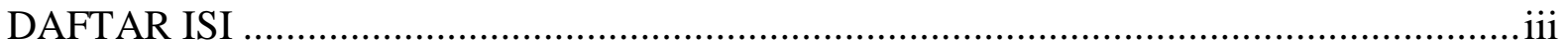

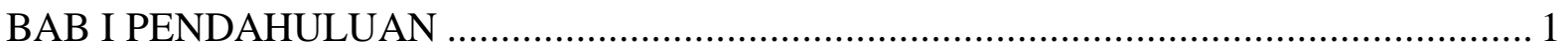

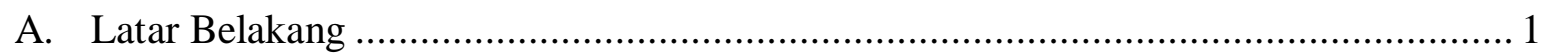

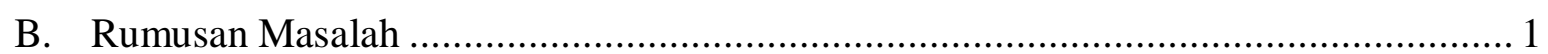

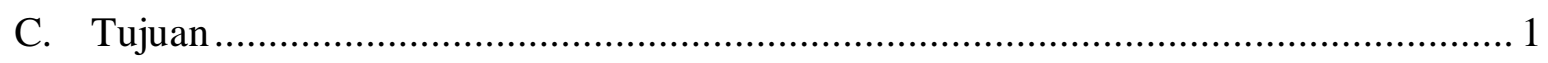

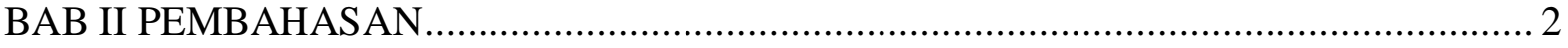

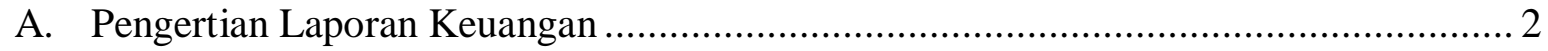

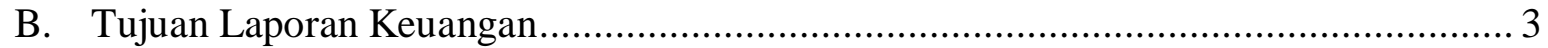

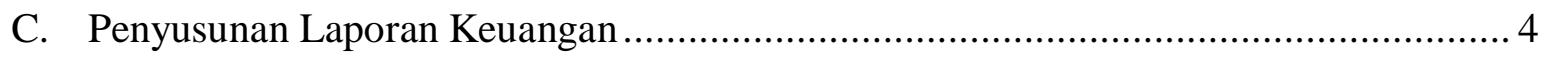

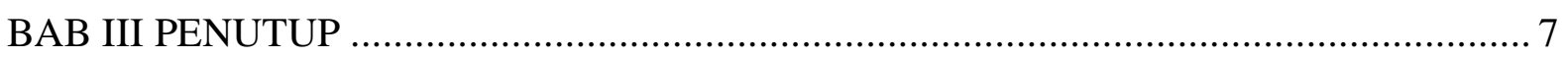

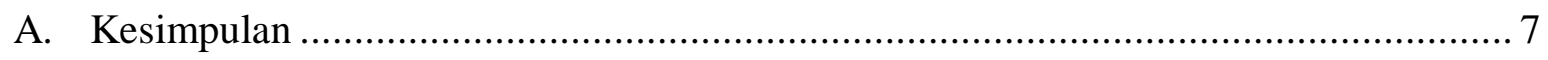

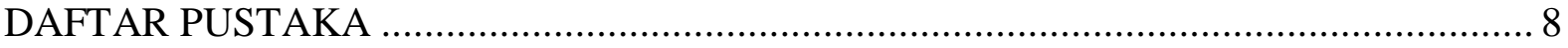




\section{BAB I \\ PENDAHULUAN}

\section{A. Latar Belakang}

Untuk menjalankan bisnis tidak boleh sembarangan. Diperlukan pengetahuan yang memadai terkait usaha beserta aktifitas yang ada di dalamnya, salah satunya adalah persoalan laporan keuangan. Keuangan merupakan unsur terpenting di dalam bisnis, karena ini yang menjadi penentu usaha akan berkembang atau sebaliknya. Atas dasar itu, untuk membangun bisnis dari awal dibutuhkan akuntan atau seorang yang mengelola keuangan bisnis yang terampil dan berpengalaman. Sayangnya tidak semua orang mengetahui pengertian dan pentingnya laporan keuangan. Bahkan seorang karyawan di bagian finance pun sulit mendefinisikan fungsi laporan keuangan bagi perusahaan. Akibatnya pembuatan laporan ini sering ala kadarnya saja dan tidak sesuai standar yang berlaku.

\section{B. Rumusan Masalah}

Berdasarkan latar belakang diatas, muncul lah pertanyaan-pertanyaan sebagai berikut:

a. Apa yang dimakasud dengan laporan keuangan?

b. Apa tujuan laporan keuangan?

c. Bagaimana penyusunan laporan keuangan?

\section{Tujuan}

Berdasarkan rumusan masalah tersebut, maka tujuan dari makalah ini adalah sebagai berikut:

a. Untuk mengetahui pengertian laporan keuangan

b. Untuk mengetahui tujuan laporan keuangan

c. Untuk mengetahui penyusunan laporan keuangan 


\section{BAB II \\ PEMBAHASAN}

\section{A. Pengertian Laporan Keuangan}

Menurut IAI (Ikatan Akuntan Indonesia) berdasarkan PSAK 1 paragraf 10 (2012), laporan keuangan adalah suatu penyajian secara tersrtuktur dari posisi keuangan dan kinerja keuangan entitas. Laporan keuangan menyajikan informasi mengenai entitas meliputi aset, liabilitas, ekuitas, pendapatan dan beban yang termasuk keuntungan dan kerugian, kontribusi, serta arus kas. Dengan adanya suatu entitas yang disajikan maka dapat digunakan untuk pembuatan keputusan ekonomi (Setyawati \& Hermawan, 2018).

Laporan keuangan menurut Munawir adalah "laporan hasil dari proses akuntansi yang dapat digunakan sebagai alat untuk berkomunikasi antara data keuangan atau aktivitas suatu perusahaan dengan pihak-pihak yang berkepentingan dengan data atau aktivitas perusahaan tersebut". Menurut IAI (2009) "laporan keuangan merupakan bagian dari proses pelaporan keuangan. Laporan keuangan yang lengkap biasanya meliputi neraca, laporan laba rugi, laporan posisi keuangan ( yang disajikan dalam berbagai cara seperti misalnya sebagai laporan arus kas atau laporan arus dana), catatan-catatan dan berbagai integral dari laporan keuangan”. Menurut Kasmir (2012) "dalam praktiknya laporan keuangan oleh perusahaan tidak dibuat secara serampangan, tetapi harus dibuat dan disusun sesuai dengan aturan atau standar yang berlaku. Hal ini dilakukan agar laporan keuangan mudah dibaca dan dimengerti".

Laporan keuangan merupakan catatan informasi suatu perusahaan pada periode akuntansi yang menggambarkan kinerja perusahaan tersebut. Laporan keuangan berguna bagi banker, kreditor, pemilik dan pihak-pihak yang berkepentingan dalam menganalisi serta menginterpretasikan kinerja keuangan dan kondisi perusahaan

Laporan keuangan adalah hasil dari proses akuntansi yang menyediakan informasi keuangan suatu perusahaan yang bermanfaat bagi pihak-pihak yang berkepentingan didalam pengambilan keputusan ekonomi. Laporan Keuangan terdiri dari lima macam, yaitu Laporan Laba/Rugi, Neraca, Perubahan Modal, Arus Kas, serta Catatan Atas Laporan Keuangan. 


\section{B. Tujuan Laporan Keuangan}

Menurut IAI tujuan laporan keuangan adalah untuk menyediakan informasi posisi keuangan dan kinerja suatu entitas yang bermanfaat bagi sejumlah besar pengguna dalam pengambilan keputusan ekonomik oleh siapapun yang tidak dalam posisi dapat meminta laporan keuangan khusus untuk memenuhi kebutuhan informasi tersebut. Pengguna tersebut meliputi penyedia sumber daya bagi entitas, seperti kreditor maupun investor. Dalam memenuhi tujuannya, laporan keuangan juga menunjukkan pertanggungjawaban manajemen atas sumber daya yang dipercayakan kepadanya.

Menurut Irham Tujuan laporan keuangan secara umum terdiri dari:

1. Untuk memberikan informasi kepada pihak yang membutuhkan tentang kondisi suatu perusahaan dari sudut angka-angka dalam satuan moneter.

2. Menyediakan informasi yang bermanfaat bagi pembuat keputusan bisnis dan ekonomis oleh investor yang ada dan yang profesional, kreditur, manajemen, pemerintah, dan pengguna lainnya.

3. Menyediakan informasi yang menyangkut posisi keuangan, kinerja serta perubahan posisi keuangan suatu perusahaan yang bermanfaat bagi sejumlah besar pemakai dalan pengambilan keputusan ekonomi.

4. Memberikan informasi tenteng posisi keuangan, kinerja perubahan ekuitas, arus kas dan informasi lainnya (Ningtyas, 2017).

Sedangankan menurut Kasmir tujuan pembuatan atau penyusunan laporan keuangan yaitu :

1. Untuk Memberikan suatu informasi perihal jenis dan jumlah aktiva (harta) yang dimiliki oleh perusahaan pada saat ini.

2. Untuk Memberikan informasi perihal jenis dan jumlah kewajiban dan modal yang dimiliki oleh perusahaan pada saat ini.

3. Untuk Memberikan informasi perihal jenis dan jumlah pendapatan yang diperoleh pada suatu periode tertentu perusahaan.

4. Untuk Memberikan informasi perihal jumlah biaya dan jenis biaya yang dikeluarkan perusahaan dalam suatu periode tertentu.

5. Untuk Memberikan informasi perihal perubahan-perubahan yang terjadi terhadap aktiva, pasiva, dan modal perusahaan. 
6. Untuk Memberikan informasi perihal kinerja manajemen perusahaan dalam periode akuntansi.

7. Untuk Memberikan informasi tentang catatan-catatan atas laporan keuangan

8. Untuk Informasi keuangan lainnya

\section{Penyusunan Laporan Keuangan}

Informasi posisi keuangan entitas terdiri dari informasi mengenai asset, liabilitas, dan ekuitas entitas pada tanggal tertentu, dan disajikan dalam laporan posisi keuangan. Berdasarkan SAK-EMKM unsur-unsur tersebut didefinisikan sebagai berikut:

1. Asset adalah sumber daya yang dikuasai oleh entitas sebagai akibat dari peristiwa masa lalu dan yang dari manfaat ekonomik dimasa depan diharapkan akan diperoleh entitas

2. Liabilitas adalah kewajiban kini entitas yang timbul dari peristiwa masa lalu yang penyelesaiannya mengakibatkan arus keluar dari sumber daya entitas yang mengandung manfaat ekonomik

3. Ekuitas adalah hak residual atas asset entitas setelah dikurangi seluruh liabilitasnya Informasi kinerja entitas terdiri dari informasi mengenai penghasilan dan beban selama periode pelaporan, dan disajikan dalam laporan laba rugi.

a. Penghasilan (income) adalah kenaikan manfaat ekonomik selama periode pelaporan dalam bentuk arus kas masuk atau kenaikan asset, atau penurunan liabilitas yang mengakibatkan kenaikan ekuitas yang tidak berasal dari kontribusi penanam modal

b. Beban (expenses) adalah penurunan manfaat ekonomik selama periode pelaporan dalam bentuk arus kas keluar atau penurunan asset, atau kenaikan liabilitas yang mengakibatkan penurunan ekuitas yang tidak disebabkan oleh distribusi kepada penanam modal.

Dasar Pengukuran unsur laporan keuangan dalam SAK EMKM adalah biaya historis. Biaya historis suatu asset adalah sebesar jumlah kas atau setara kas yang dibayarkan untuk memperoleh asset tersebut pada saat perolehan. Biaya historis suatu liabilitas adalah sejumlah kas atau setara kas yang diterima atau jumlah kas yang diperkirakan akan dibayarkan untuk memenuhi liabilitas dalam pelaksanaan usaha normal. 
Pengakuan unsur laporan keuangan merupakan proses pembentukan suatu pos dalam laporan keuangan atau laporan aba rugi yang memenuhi kriteria :

a. Manfaat ekonomik yang terkait dengan pos-pos asset, liabilitas, penghasilan dan beban dapat dipastikan akan mengalir ke dalam atau keluar dari entitas

b. Pos-pos tersebut memiliki biaya yang dapat dikukur dan andal.

Pengungkapan diperlukan ketika kepatuhan atas persyaratan tertentu dalam SAK EMKM tidak memadai bagi pemakai untuk memahami pengaruh dari transaksi, peristiwa dan kondisi lain atas posisi dan kinerja keuangan entitas. Penyajian wajar laporan keuangan mensyaratkan entitas untuk menyajikan informasi yang relevan, representative tepat, keterbandingan, dan keterpahaman. Entitas menyajikan secara lengkap laporan keuangan pada akhir setiap periode pelaporan. Laporan keuangan minimal terdiri dari :

a. Laporan posisi keuangan pada akhir periode

b. Laporan laba rugi selama periode

c. Catatan atas laporan keuangan yang berisi tambahan dan rincian pos-pos tertentu yang relevan.

Laporan posisi keuangan entitas mencakup pospos berikut :

a) Kas dan setara kas

b) Piutang

c) Persediaan

d) Asset tetap

e) Utang usaha

f) Utang bank

g) Ekuitas

Laporan laba rugi entitas mencakup pos-pos berikut :

a) Pendapatan

b) Beban keuangan

c) Beban pajak

Catatan atas laporan keuangan memuat :

a) Suatu pernyataan bahwa laporan keuangan telah disusun sesuai SAK EMKM 
b) Ikhtisar kebijakan akuntansi

c) Informasi tambahan dan rincian pos tertentu yang menjelaskan transaksi penting dan material sehingga bermanfaat bagi pengguna untuk memahami laporan keuangan. 


\section{BAB III \\ PENUTUP}

\section{A. Kesimpulan}

Berdasarkan pembahasan dari makalah ini maka dapat ditarik kesimpulan Laporan keuangan adalah hasil dari proses akuntansi yang menyediakan informasi keuangan suatu perusahaan yang bermanfaat bagi pihak-pihak yang berkepentingan didalam pengambilan keputusan ekonomi. Laporan Keuangan terdiri dari lima macam, yaitu Laporan Laba/Rugi, Neraca, Perubahan Modal, Arus Kas, serta Catatan Atas Laporan Keuangan. Tidak hanya itu, tujuan laporan keuangan adalah untuk menyediakan informasi posisi keuangan dan kinerja suatu entitas yang bermanfaat bagi sejumlah besar pengguna dalam pengambilan keputusan ekonomik oleh siapapun yang tidak dalam posisi dapat meminta laporan keuangan khusus untuk memenuhi kebutuhan informasi tersebut. 


\section{DAFTAR PUSTAKA}

Ningtyas, J. D. (2017). Penyusunan Laporan Keuangan UMKM Berdasarkan Standar Akuntansi Keuangan Entitas Mikro, Kecil dan Menengah (SAK-EMKM) (Study Kasus Di UMKM Bintang Malam Pekalongan). Riset \& Jurnal Akuntansi , 2 (1), 11-17.

Setyawati, Y., \& Hermawan, S. (2018). Persepsi Pemilik dan Pengetahuan Akuntansi Pelaku Usaha Mikro Kecil dan Menengah (UMKM) atas Penyusunan Laporan Keuangan. Riset Akuntansi dan Keuangan Indonesia , 3 (2), 161-204. 